Article

\title{
Nascent Rice Husk as an Adsorbent for Removing Cationic Dyes from Textile Wastewater
}

\author{
Jude Ofei Quansah ${ }^{1}$, Thandar Hlaing ${ }^{1}$, Fritz Ndumbe Lyonga ${ }^{1}{ }^{(}$, Phyo Phyo Kyi $^{1}{ }^{(\mathbb{O}}$, \\ Seung-Hee Hong ${ }^{2}$, Chang-Gu Lee ${ }^{3}$ and Seong-Jik Park ${ }^{4, *(D)}$ \\ 1 Department of Chemical Engineering, Hankyong National University, Anseong 17579, Korea; \\ judequanres2018@gmail.com (J.O.Q.); thandarhlaing.che@gmail.com (T.H.); \\ fritzlyonga79@gmail.com (F.N.L.); phyophyokyi17@gmail.com (P.P.K.) \\ 2 Department of Integrated Systems Engineering, Hankyong National University, Anseong 17579, Korea; \\ trea1568@naver.com \\ 3 Department of Environmental and Safety Engineering, Ajou University, Suwon 16499, Korea; \\ changgu@ajou.ac.kr \\ 4 School of Social Safety and Systems Engineering, Hankyong National University, Anseong 17579, Korea \\ * Correspondence: parkseongjik@hknu.ac.kr; Tel.: +82 31670513
}

Received: 25 April 2020; Accepted: 13 May 2020; Published: 15 May 2020

\begin{abstract}
We assessed the applicability of rice husk (RH) to remove cationic dyes, i.e., methylene blue (MB) and crystal violet (CV), from water. $\mathrm{RH}$ thermally treated at $75{ }^{\circ} \mathrm{C}$ showed a higher adsorption capacity than that at high temperatures $\left(300-700^{\circ} \mathrm{C}\right)$. For a suitable CV-adsorption model, a pseudo-first-order model for $\mathrm{MB}$ adsorption was followed by the kinetics adsorption process; however, a pseudo-second-order model was then suggested. In the $\mathrm{q}_{t}$ versus $\mathrm{t}^{1 / 2}$ plot, the MB line passed through the origin, but that of CV did not. The Langmuir isotherm model was better than the Freundlich model for both dye adsorptions; furthermore, the adsorption capacity for MB and CV was $24.48 \mathrm{mg} / \mathrm{g}$ and $25.46 \mathrm{mg} / \mathrm{g}$, respectively. Thermodynamically, the adsorption of both MB and CV onto the RH was found to be spontaneous and endothermic. This adsorption increased insignificantly on increasing the solution $\mathrm{pH}$ from 4 to 10 . With an increasing dosage of the $\mathrm{RH}$, there was an increase in the removal percentages of $\mathrm{MB}$ and $\mathrm{CV}$; however, adsorption capacity per unit mass of the RH was observed to decrease. Therefore, we conclude that utilizing RH as an available and affordable adsorbent is feasible to remove MB and CV from wastewater.
\end{abstract}

Keywords: rice husk; adsorption; crystal violet; methylene blue; thermal treatment

\section{Introduction}

Effluents from textile, leather, cosmetics, paper, pulp and dye manufacturing industries are highly colored because they contain organic chemicals called dyes [1]. The various types of dyes include methylene blue $(\mathrm{MB})$ and crystal violet $(\mathrm{CV})$. $\mathrm{MB}$ is an odorless, dark green powder that turns blue in an aqueous solution; it is used for dying cotton or silk, surgeries, and as a hair-colorant [2-4]. However, on direct contact, MB causes eye-burns and nausea, and, on ingestion, vomiting and profuse sweating [5]. $\mathrm{CV}$, a protein-based dye also known as gentian violet, is used to enhance bloody-fingerprints and on adhesive tapes to prevent adhesion of powders on their sticky sides [6]. Conversely, CV is carcinogenic, recalcitrant, and non-biodegradable in nature [7]. Therefore, disposal of colored wastewater into an aquatic environment causes reduced photosynthesis due to low light penetration [8], and mutagenesis in both aquatic organisms and humans [9].

Several dye-removal methods have been investigated of late, which include biological [10], and physio-chemical technologies [11,12]. Photochemical and advanced oxidation process [13-15], 
electro kinetic coagulation [16], flocculation [17], nano filtration [18], adsorption [19], and reverse osmosis [20] have also been found to be impressive in removing dye contaminants from aqueous solutions. On the other hand, the majority of these methods are relatively expensive and energy-demanding [21,22]. Biological treatment processes are inefficient due to the non-biodegradability of dyes [11]. Therefore, dye-removal from effluents using adsorption has been found to be more desirable and effective in developing countries [23,24]. This is because adsorption exhibits simplicity, design flexibility, high contaminant selectivity, low operational cost, and ensures excellent treated-effluent quality $[25,26]$.

In recent years, many researchers have focused on developing cheaper adsorbents for dye-removal such as peanut husk [27], wheat straw [28], seed husk [29], walnut shells [30], straw dust [31,32], orange peel [33], date stones [34], cashew nut shell [35], and plum kernel [36]. These agricultural by-products are being increasingly used due to their low ash content, good mechanical strength, few processing needs, superior adsorption potential, availability, and regenerative ability [37-39]

Rice husk (RH), a major by-product of the rice milling industry is abundant and readily available [40], accounting for $20 \%$ of global gross rice-paddy production, which is estimated to be at 190 million tons as of 2016 [41]. Vietnam and Myanmar together account for 69 million tons of rice production ( $>7.20 \%$ of global production), thereby, producing 13.8 million tons of $\mathrm{RH}$ as by-product [42]. Thus, possible use of RH will yield high economic and environmental benefits [43,44]. RH has been found to consist mainly of $32 \%$ cellulose, $20 \%$ silica, $3 \%$ crude proteins, and $21 \%$ of both hemicelluloses and lignin [45]. Furthermore, chemical stability, good intrinsic strength, inherent resistance, and a silica-cellulose structural arrangement characterize RH [45,46].

Here, $\mathrm{RH}$ was an adsorbent to remove $\mathrm{MB}$ and $\mathrm{CV}$ from water under batch experimental conditions. $\mathrm{MB}$ and $\mathrm{CV}$ were selected for being cationic, strongly colored, non-biodegradable, mutagenic, and carcinogenic even in very small doses and at short exposure periods [47-49]. The impact of thermal treatment on the RH adsorption potential was assessed under different temperatures. The sorption characteristics of $\mathrm{MB}$ and $\mathrm{CV}$ on the $\mathrm{RH}$ were further explored by performing kinetic, equilibrium, thermodynamic, $\mathrm{pH}$, and competitive anion adsorption experiments. In addition, model studies for kinetic, equilibrium, and thermodynamic adsorption experiments were also conducted to elucidate the adsorption characteristics and their mechanisms.

\section{Materials and Methods}

\subsection{Preparation of Adsorbate Solution}

MB ( $\geq 82.0 \%$ dye content) and CV ( $\geq 90 \%$ anhydrous basis) of analytical grades purchased from Sigma-Aldrich, Korea, were used here. Amounts of $1000 \mathrm{mg} / \mathrm{L} \mathrm{MB}$ and CV stock solutions were made by mixing $1 \mathrm{~g}$ of the dye (MB and $\mathrm{CV}$ ) with $1 \mathrm{~L}$ deionized water in a volumetric flask. The solutions were conserved in a dark place to impede depolarization.

\subsection{Thermal Treatment and Characterization of Rice Husk}

The RH was acquired from Oryza sativa L. cultivated in paddy fields, Anseong City, Republic of Korea. It was rinsed with distilled water to remove dirt and other contaminants, followed by drying in an oven for $24 \mathrm{~h}$ at $80^{\circ} \mathrm{C}$ to reduce moisture content after which it was ground and strained using a 30-mesh standard sieve $(0.595 \mathrm{~mm})$. The impact of thermic operations on the adsorption capacity of the $\mathrm{RH}$ for MB was evaluated. A conventional tube furnace with a horizontal stainless-steel tube (diameter: $5.5 \mathrm{~cm}$; length: $55 \mathrm{~cm}$ ) at various temperatures $\left(75^{\circ} \mathrm{C}, 100{ }^{\circ} \mathrm{C}, 300{ }^{\circ} \mathrm{C}, 500{ }^{\circ} \mathrm{C}\right.$, and $\left.700{ }^{\circ} \mathrm{C}\right)$ was used to activate the $\mathrm{RH}$ under anoxic conditions. For the comparison, $\mathrm{RH}$ dried at room temperature (RT) was also used. The samples were labeled as untreated RH (RH), RH-75, RH-100, RH-300, RH-500, and RH-700, respectively. A field emission-scanning electron microscope (FE-SEM, S4700, Hitachi, Japan) was employed to inspect the surface morphologies of the RH. $\mathrm{N}_{2}$ adsorption-desorption experiments were performed to measure the specific surface area of $\mathrm{RH}$ using a surface area analyzer 
(Quadrasorb SI, Quantachrome Instrument, USA). From the $\mathrm{N}_{2}$ adsorption-desorption isotherms, the specific surface area, pore volume, and pore diameter were determined by Brunauer-Emmett-Teller (BET) analysis using a surface area analyzer.

\subsection{Batch Adsorption Experiments}

The RH was employed to elucidate the removal of $\mathrm{MB}$ and $\mathrm{CV}$ under batch conditions. The concentrations for MB and CV were set to be $300 \mathrm{mg} / \mathrm{L}$ and $400 \mathrm{mg} / \mathrm{L}$, respectively, and they were made from $\mathrm{MB}$ and $\mathrm{CV}$ stock solutions $(1000 \mathrm{mg} / \mathrm{L})$. Batch adsorption tests were carried out by reacting $0.5 \mathrm{~g}$ of the $\mathrm{RH}$ with $30 \mathrm{~mL}$ dye solutions (MB and $\mathrm{CV}$ ) in a $50 \mathrm{~mL}$ polypropylene tube using a quivering incubator with a stirring rate of $100 \mathrm{rpm}$ and temperature of $25^{\circ} \mathrm{C}$. Kinetic experiments were conducted by differing the reaction time $(0.5-24 \mathrm{~h})$ under the concentrations of $300 \mathrm{mg} / \mathrm{L}$ and $400 \mathrm{mg} / \mathrm{L}$ for $\mathrm{MB}$ and $\mathrm{CV}$, respectively. Equilibrium adsorption analyses were conducted using diverse initial concentrations (10-500 mg/L) for MB and CV, respectively; the samples were tested after $24 \mathrm{~h}$. Thermodynamic analyses were carried out by mixing the RH $(0.5 \mathrm{~g})$ with $30 \mathrm{~mL}$ of $300 \mathrm{mg} / \mathrm{L}(\mathrm{MB})$ and $400 \mathrm{mg} / \mathrm{L}(\mathrm{CV})$ solutions at reaction temperatures of $15^{\circ} \mathrm{C}, 25^{\circ} \mathrm{C}$, and $35^{\circ} \mathrm{C}$ for $24 \mathrm{~h}$. The influence of solution $\mathrm{pH}$, at different $\mathrm{pH}$ values, on $\mathrm{MB}$ and $\mathrm{CV}$ adsorption was explored. The $\mathrm{pH}$ of each solution was altered from 4 to 10 using $0.1 \mathrm{M} \mathrm{HCl}$ and $0.1 \mathrm{M} \mathrm{NaOH}$; the adjusted $\mathrm{pH}$ was then measured with a pH meter (9107BN, Thermo Scientific, USA). The influence of adsorbent dosage on MB and $\mathrm{CV}$ adsorption by $\mathrm{RH}$ was investigated by reacting various doses of the $\mathrm{RH}(0.05-0.5 \mathrm{~g}$ for $\mathrm{MB}$ and 0.1-1.0 $\mathrm{g}$ for CV) with $30 \mathrm{~mL}$ of each dye at initial concentrations of $300 \mathrm{mg} / \mathrm{L}(\mathrm{MB})$ and $400 \mathrm{mg} / \mathrm{L}$ (CV). The none-adsorbed concentrations of $\mathrm{MB}$ and $\mathrm{CV}$ in aqueous solution were measured with a UV-visible spectrophotometer (Optizen POP QX, Mecasys Co., Korea) at wavelengths of $668 \mathrm{~nm}$ and $590 \mathrm{~nm}$, respectively. All the experiments were performed three times.

Kinetics adsorption results were analyzed using pseudo-first-order (PFO), pseudo-second-order (PSO) and intra-particle diffusion (IPD) models [50-52]. Equilibrium isothermal adsorption data were modeled with the Langmuir and Freundlich models [50,51]. Thermodynamic parameters were explored using the equations published in literatures [50,51].

\section{Results and Discussion}

\subsection{Impact of Thermal Treatment on the Adsorption Capacity of Rice Husk}

Figure 1 depicts the adsorption capacity of RH under different temperatures from RT- $700{ }^{\circ} \mathrm{C}$ with two initial $\mathrm{MB}$ concentrations ( 300 and $500 \mathrm{mg} / \mathrm{L}$ ). At $300 \mathrm{mg} / \mathrm{L}$, the $\mathrm{MB}$ adsorption by untreated rice was similar to that of $\mathrm{RH}$ treated at $75^{\circ} \mathrm{C}$ and $100{ }^{\circ} \mathrm{C}$, respectively, but was larger than that obtained under high temperatures $\left(300-700^{\circ} \mathrm{C}\right)$. The low adsorption of $\mathrm{RH}$ treated under the high temperatures was also observed when the initial MB concentration was $500 \mathrm{mg} / \mathrm{L}$. These outcomes revealed that pyrolysis of the RH under high temperatures did not improve the adsorption of MB. The RH treated at $75{ }^{\circ} \mathrm{C}$ showed higher $\mathrm{MB}$ adsorption than untreated $\mathrm{RH}$ and that treated at $100{ }^{\circ} \mathrm{C}$. MB adsorption capacity slightly increased from $25.64 \mathrm{mg} / \mathrm{g}$ at RT to $27.58 \mathrm{mg} / \mathrm{g}$ at $75^{\circ} \mathrm{C}$.

Lower temperatures resulted in higher adsorption efficiency. The decrease in adsorption capacity was ascribed to the certainty that, at higher temperatures, the RH surface melts; and due to high silica content, it is easily transformed to crystabolites, which cause partial blockage of pores $[53,54]$. The specific surface area and pore and pore diameter were determined by Brunauer-Emmett-Teller analysis and those showed that the RH without thermal treatment had the highest surface-area $\left(35.14 \mathrm{~m}^{2} / \mathrm{g}\right)$ and smallest pore diameter $(5.11 \mathrm{~nm})$. However, with increasing temperature, a smaller specific surface-area and bigger pore-diameter were obtained-as for RH-100 $\left(24.63 \mathrm{~m}^{2} / \mathrm{g}\right.$ and $\left.6.34 \mathrm{~nm}\right)$ and RH-300 $\left(18.38 \mathrm{~m}^{2} / \mathrm{g}\right.$ and $\left.7.56 \mathrm{~nm}\right)$-due to high silica content, which contributes to agglomeration, reducing the porosity of $\mathrm{RH}$ and is consistent with other literature [55,56]. Surface morphology of the $\mathrm{RH}$ treated at different temperatures was studied with FE-SEM; the results are depicted in Figure 2. 
All thermally treated RH was observed to have nodule-like surfaces structures; increased temperature caused their destruction, resulting in the reduction of specific surface-area.

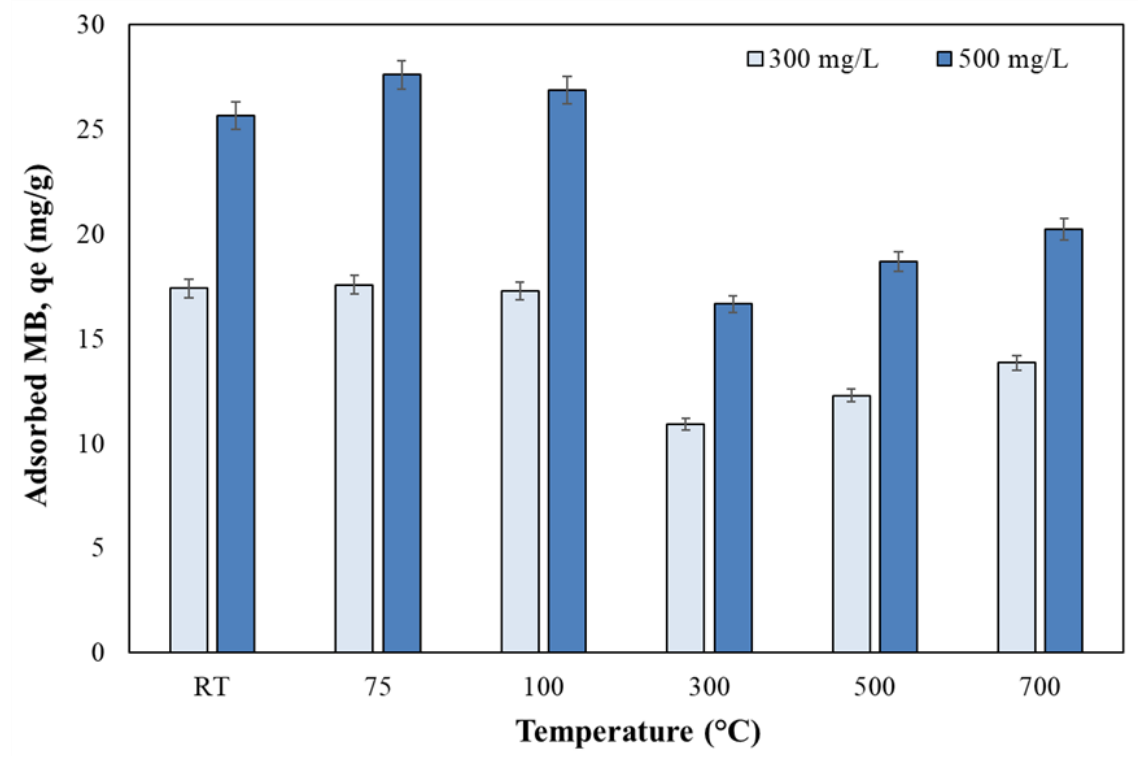

Figure 1. Impact of thermal treatment on methylene blue (MB) adsorption capacity onto rice husk.
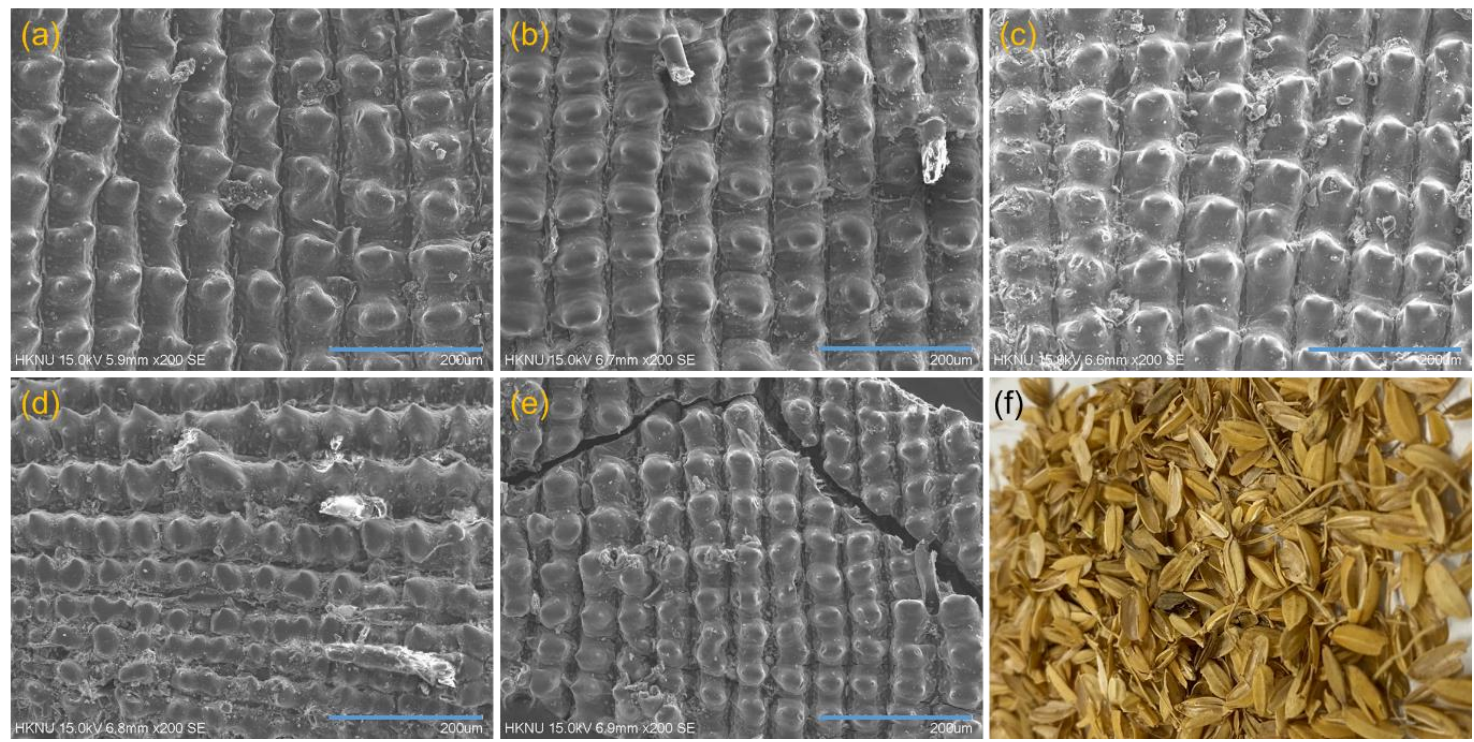

Figure 2. Field emission-scanning electron microscope photos of rice husk thermally treated. (a) Room temperature, (b) $75^{\circ} \mathrm{C}$, (c) $100^{\circ} \mathrm{C}$, (d) $300^{\circ} \mathrm{C}$, (e) $500{ }^{\circ} \mathrm{C}$. (Magnification: $\times 200$; Scale: $\left.200 \mu \mathrm{m}\right)$. (f) Digital image of rice husk used in this study.

\subsection{Kinetic Studies}

The experimental data for $\mathrm{MB}$ and $\mathrm{CV}$ adsorption onto $\mathrm{RH}$ as a function of reaction-time were represented in Figure 3, with PFO and PSO kinetic model fits. The rates of adsorption for both dyes (MB and CV) were fast during the first $15 \mathrm{~min} ; 16.56 \mathrm{mg} / \mathrm{g}(\mathrm{MB})$ and $18.20 \mathrm{mg} / \mathrm{g}(\mathrm{CV})$ were adsorbed, respectively. Equilibrium was attained within $3 \mathrm{~h}$ for $\mathrm{MB}$ but the adsorbed amounts for $\mathrm{CV}$ increased continuously during $24 \mathrm{~h}$. The fast increase in the adsorbed dye amount was ascribed to enough vacant adsorption sites at the beginning, leading to easy access of dyes to adsorption sites $[57,58]$. The slow adsorption-rate at equilibrium was owed to overloading of favorable active sites [8]. 


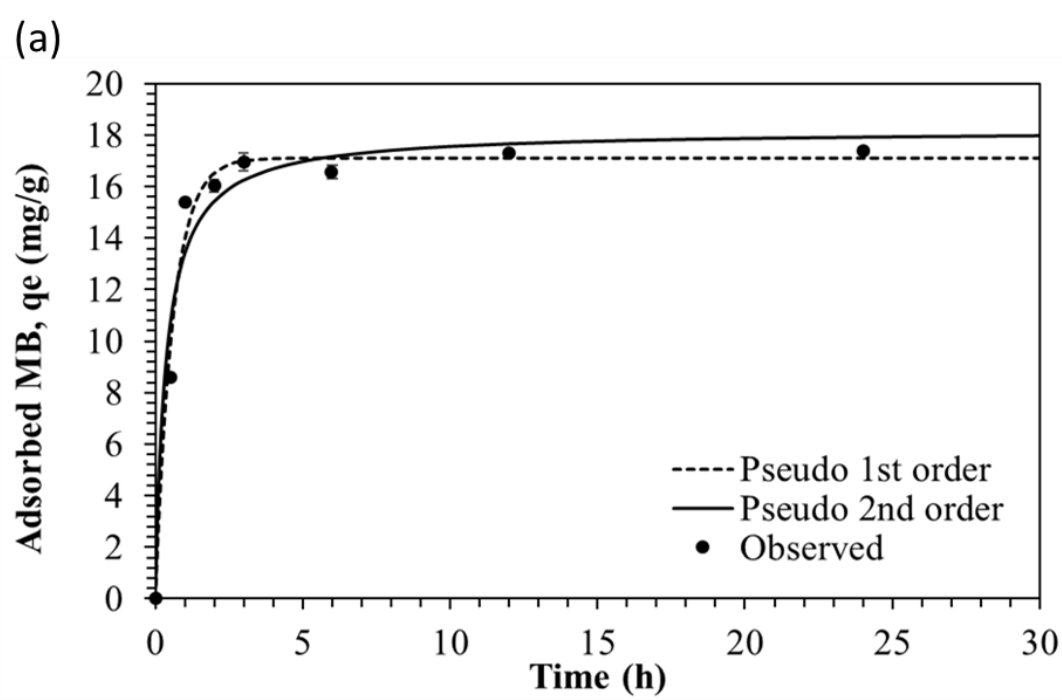

(b)

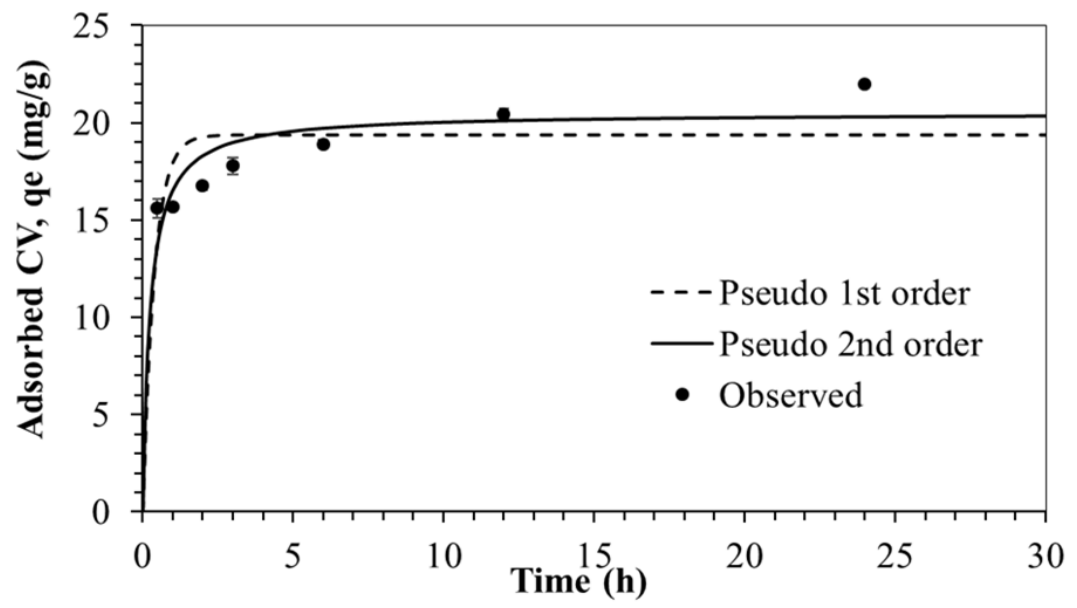

Figure 3. The kinetic profile represented by the pseudo-first order and pseudo-second-order for (a) methylene blue $(\mathrm{MB})$ adsorption and (b) crystal violet $(\mathrm{CV})$ adsorption

To investigate the mechanism involved in the adsorption process, the PFO and PSO models demonstrated a relatively high correlation coefficient $\left(R^{2}\right)$ for $M B$ and $C V$ as depicted in Table 1 . The $\mathrm{PFO}$ model best represents $\mathrm{MB}$ adsorption, divulging that the sorption rate involves either intra-particle or film-diffusion $[59,60]$. The PSO kinetic model best fits CV adsorption, indicating a chemisorption process involving ionic exchange and valence forces via the splitting or swapping of electrons between the RH and CV [61].

Table 1. Pseudo-first-order and pseudo-second-order model parameters for methylene blue (MB) and crystal violet $(\mathrm{CV})$ adsorption onto rice husk. $q_{e}$ : the amount of adsorbed dyes at equilibrium (mg/g); $k_{1}$ : PFO rate constant $(1 / \mathrm{h}) ; k_{2}$ : PSO rate constant $(\mathrm{g} / \mathrm{mg} / \mathrm{h})$.

\begin{tabular}{|c|c|c|c|c|c|c|}
\hline \multirow{2}{*}{ Adsorbate } & \multicolumn{3}{|c|}{ Pseudo-First-Order Kinetics } & \multicolumn{3}{|c|}{ Pseudo-Second-Order Kinetics } \\
\hline & $q_{e}(\mathrm{mg} / \mathrm{g})$ & $k_{1}(1 / \mathrm{h})$ & $R^{2}$ & $q_{e}(\mathrm{mg} / \mathrm{g})$ & $k_{2}(\mathrm{~g} / \mathrm{mg} / \mathrm{h})$ & $R^{2}$ \\
\hline MB & 17.1038 & 1.6835 & 0.9848 & 18.1906 & 0.1537 & 0.9641 \\
\hline $\mathrm{CV}$ & 18.9546 & 2.8671 & 0.9185 & 20.2015 & 0.2275 & 0.9649 \\
\hline
\end{tabular}

The kinetic data was also explored using an IPD model. In order to explore the relevance of the IPD model, the amount adsorbed, $q_{t}$, vs. the square root of time, $\mathrm{t}^{1 / 2}$, adsorption of MB and CV onto $\mathrm{RH}$ at different conditions are mapped according to the theory proposed by Weber and Morris [52]. 
Figure 4a presents that the rate limiting process is not only influenced by intra-particle diffusion during the adsorption of MB onto RH. The adsorption process of MB involved three stages of diffusion mechanisms. The first being the diffusion of MB through the solution to the external surface of the $\mathrm{RH}$, forming a boundary layer. The passage of the MB adsorption plot through the origin indicated that intra-particle diffusion controlled the adsorption-rate [62]; this was consistent with the PFO observed for the MB adsorption process. Secondly, the slow adsorption of MB through internal pores, which limited the adsorption-rate; and thirdly, the retarded rate of intra-particle diffusion caused by low MB concentration, which helps attain final equilibrium. [63,64]. MB adsorption at the final stage involved the lowest slope of 0.2062 and the highest intercept of 16.401, indicating the largest boundary layer diffusion effect [65]. Conversely, the straight-line CV adsorption plot was observed not to pass through the origin, indicating that the adsorption-rate was not only controlled by intra-particle diffusion [66]. The one-directional linearity of CV adsorption (Figure $4 \mathrm{~b}$ ), suggests a one-stage adsorption process, involving chemisorption, which is consistent with the PSO model [67]. The difference in the adsorption mechanisms exhibited by both, $\mathrm{MB}$ and $\mathrm{CV}$, could be due to their molecular structure and differing molecular weight (MB: $319.86 \mathrm{~g} / \mathrm{mol}$; CV: $407.99 \mathrm{~g} / \mathrm{mol}$ ).
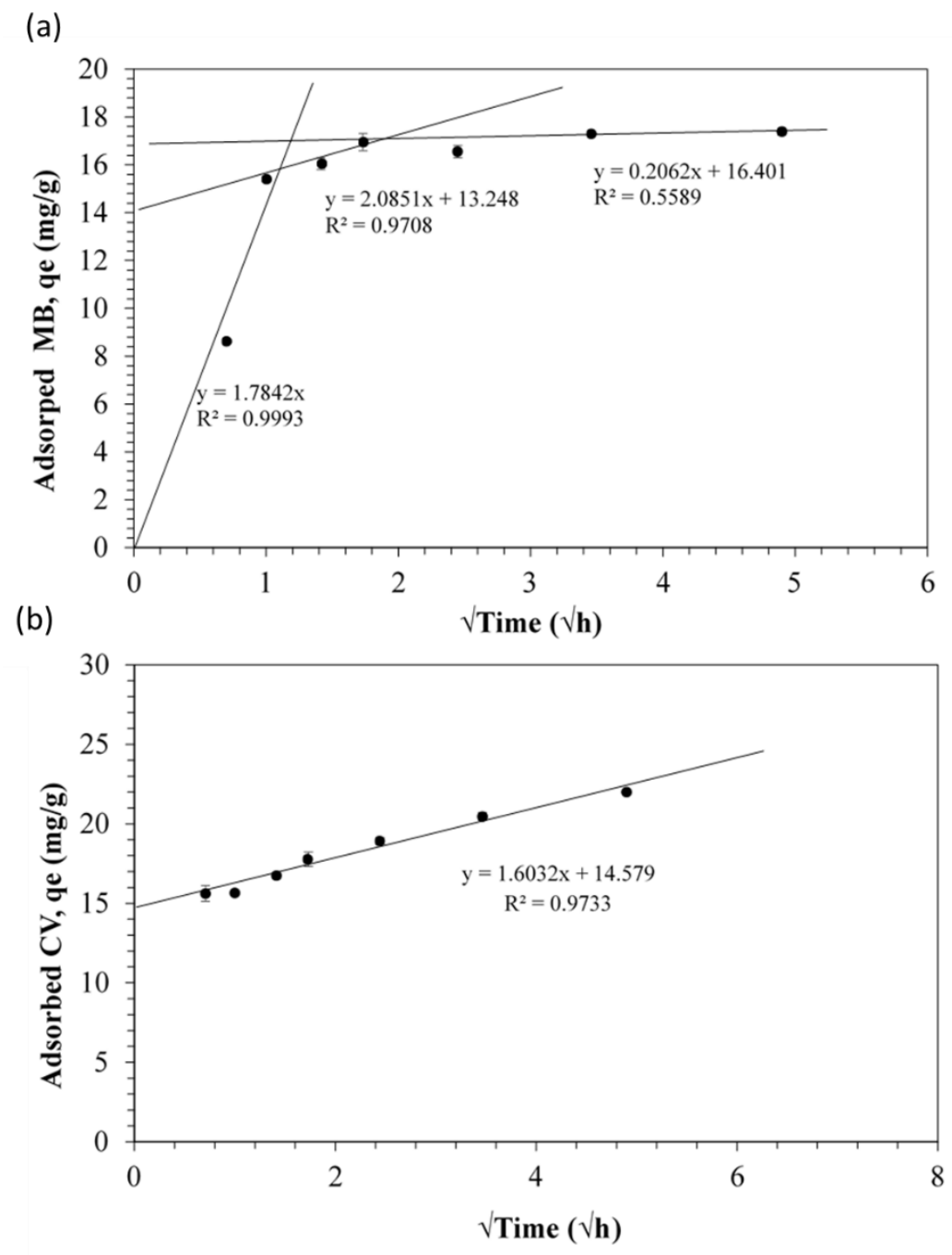

Figure 4. The kinetic profile represented by the intra-particle diffusion model for (a) methylene blue (MB) adsorption at 300-ppm concentration (b) crystal violet (CV) adsorption at 400-ppm concentration. 


\subsection{Adsorption Isotherm}

The equilibrium adsorption isotherms are indispensable in understanding the interactive nature between adsorbents and adsorbates, as they are useful in designing adsorption systems. The influence of different $\mathrm{MB}$ and CV concentrations $(0-120 \mathrm{mg} / \mathrm{L})$ was tested and presented in Figure 5, where equilibrium of the different concentrations in an aqueous phase, $C_{e}(\mathrm{mg} / \mathrm{L})$, and the amount of $M B$ and $\mathrm{CV}$ adsorbed on the $\mathrm{RH}, \mathrm{q}_{\mathrm{e}}(\mathrm{mg} / \mathrm{g})$, were plotted as a function of the equilibrium concentration of $\mathrm{MB}$ and $\mathrm{CV}$ in aqueous solution. With increasing concentrations of $\mathrm{MB}$ and $\mathrm{CV}$ in the aqueous phase (Figure 3a,b), the adsorbed amounts of $\mathrm{MB}$ and CV, respectively, increased linearly; each isotherm represented the observed data fairly well. The selection of best fit model was based on the $R^{2}$ value provided in Table 2. Thus, the adsorption data fit well with the Langmuir isotherm, with $\mathrm{R}^{2}$ values of 0.972 and 0.979 , rather than the Freundlich isotherm, for both MB and CV adsorption by the RH. The Langmuir isotherm is an equation assuming monolayer adsorption onto a uniform surface with no interaction between the adsorbed molecules, suggesting the adsorption of $\mathrm{MB}$ and $\mathrm{CV}$ on the $\mathrm{RH}$ surface as a homogenous monolayer [68]. The isotherm implies a monolayer of MB and CV over a homogenous RH surface, reaching saturation after attaining equilibrium, and making it impossible for further adsorption [69]. The CV adsorption onto almond skin waste followed a similar Langmuir isotherm [70]. Furthermore, the values of $1 / n$ for $\mathrm{MB}$ and $\mathrm{CV}$ were determined to be 0.32 and 0.28 , respectively. The $1 / \mathrm{n}$ values between 0 and 1 , indicate a favorable adsorption process [71].

(a)

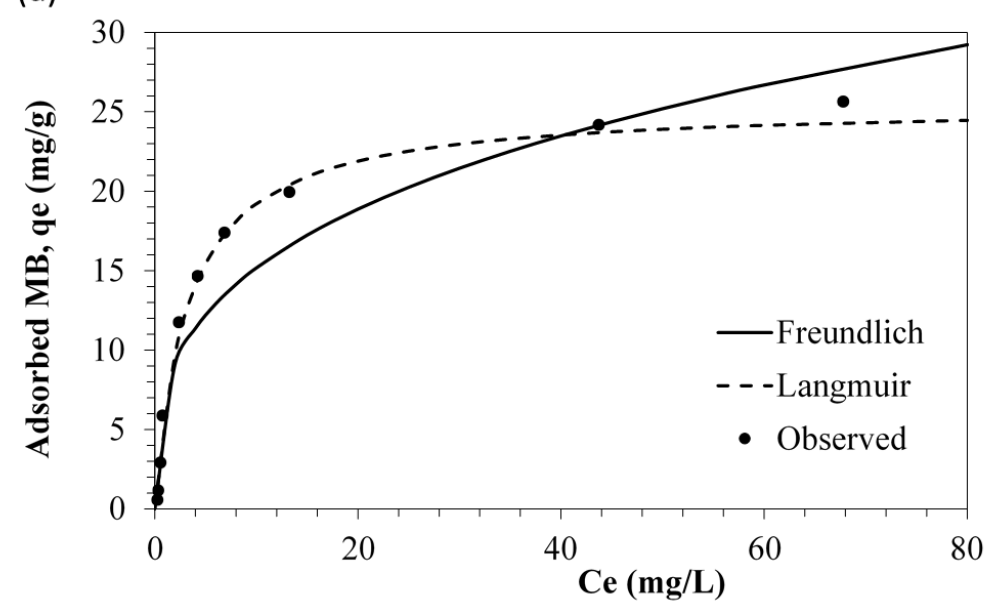

(b)

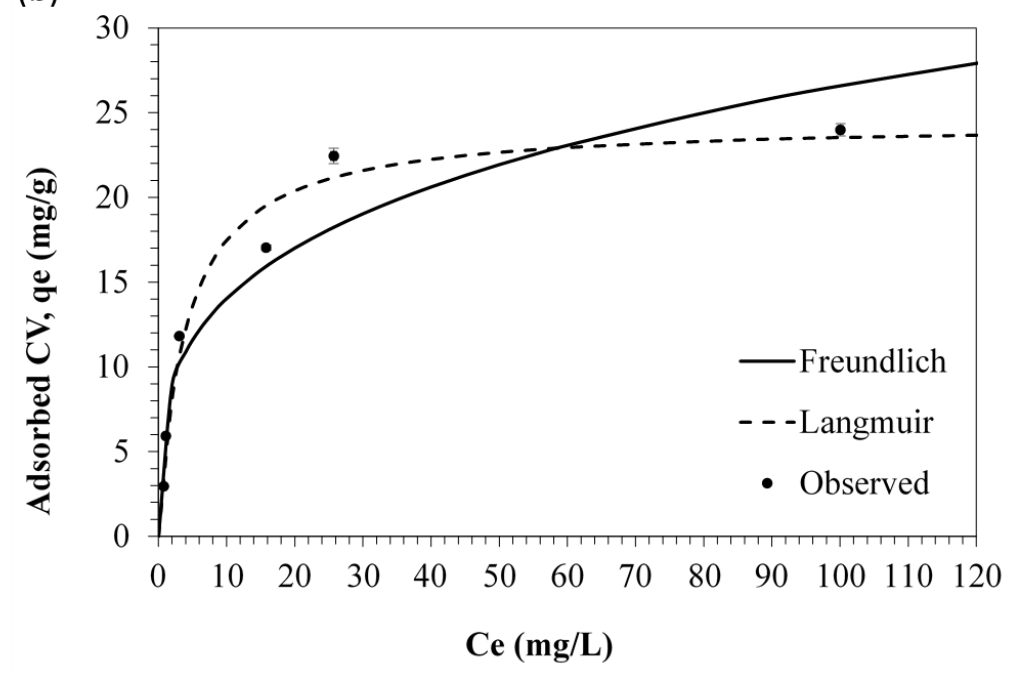

Figure 5. Freundlich and Langmuir adsorption isotherms using rice husk for (a) methylene blue (MB) and (b) crystal violet (CV). 
Table 2. Langmuir and Freundlich constants for adsorption of methylene blue (MB) and crystal violet $(\mathrm{CV})$ onto rice husk. $C_{e}$ : the dye concentration in aqueous solution after reaction $(\mathrm{mg} / \mathrm{L}) ; K_{L}$ : Langmuir adsorption constant $(\mathrm{L} / \mathrm{mg}) ; Q_{m}$ : maximum adsorption amount of dye per unit mass of $\mathrm{RH}(\mathrm{mg} / \mathrm{g}) ; K_{F}$ : distribution coefficient $(\mathrm{L} / \mathrm{g}) ; n$ : Freundlich constant.

\begin{tabular}{ccccccc}
\hline \multirow{2}{*}{ Adsorbate } & \multicolumn{3}{c}{ Langmuir Isotherm } & \multicolumn{3}{c}{ Freundlich Isotherm } \\
\cline { 2 - 7 } & $\boldsymbol{Q}_{\boldsymbol{m}} \mathbf{( \mathbf { m g } / \mathbf { g } )}$ & $\boldsymbol{K}_{\boldsymbol{L}}(\mathbf{L} / \mathbf{m g})$ & $\boldsymbol{R}^{\mathbf{2}}$ & $\boldsymbol{K}_{\boldsymbol{F}}$ & $\mathbf{1} / \boldsymbol{n}$ & $\boldsymbol{R}^{\mathbf{2}}$ \\
\hline MB & 25.4645 & 0.3068 & 0.9868 & 7.3348 & 0.3155 & 0.9062 \\
$\mathrm{CV}$ & 24.4781 & 0.2493 & 0.9785 & 7.4143 & 0.2773 & 0.9107 \\
\hline
\end{tabular}

The adsorption capacities of $\mathrm{RH}$ for $\mathrm{MB}$ and $\mathrm{CV}$ were compared with other adsorbents. The maximum amounts of MB and CV adsorbed were found to be $25.46 \mathrm{mg} / \mathrm{g}$ and $24.48 \mathrm{mg} / \mathrm{g}$, respectively. The $\mathrm{RH}$ showed a favorable adsorption capacity, even though it was low in comparison to that of various adsorbents, as shown in Table 3 for MB, and in studies by Chakraborty, S., Chowdhury, S., Saha, P.D. [44] and Sharma, P., Kaur, H., Sharma, M., Sahore, V. [72] for CV. The maximum reported capacities of the adsorbent materials ranges from $20.29 \mathrm{mg} / \mathrm{g}$ to $555.56 \mathrm{mg} / \mathrm{g}$; that of RH $(25.46 \mathrm{mg} / \mathrm{g})$ lies at the tail end of the table. It is worth mentioning that most adsorbents ranking higher also had a smaller size (nano or micron). Nano/micro-sized particles cannot be used in filtration systems without post separation process, to separate micro particles from water after treatment. The low adsorption capacity of RH could be attributed to its chemical composition, which includes lignin and silica, that cause a reduction in the bonding strength between functional groups available on its surface and an adsorbate; thus, resulting in low adsorption of MB and CV. Additionally, the surface of $\mathrm{RH}$ is smooth, containing wax and fats that shelter the grain, chemically and physically affecting its adsorption properties [73]. However, RH is readily available in Myanmar and Vietnam at an affordable price of $\sim$ USD 0.025 per $\mathrm{kg}$ [38]. Thus, the RH treated at $75^{\circ} \mathrm{C}(\mathrm{RH}-75)$ for $24 \mathrm{~h}$, with particle size of $0.075-1.16 \mathrm{~mm}$, is environmentally friendly and more cost effective as compared to other adsorbents. Firstly, the granular nature of the adsorbent is advantageous as it is easily separated after filtration and sedimentation without forming a sludge. Secondly, with regard to recycling, by utilizing an agricultural by-product, it helps to valorize waste as a resource to minimize environmental hazards.

Table 3. Comparison of methylene blue adsorption capacity to that of various adsorbents.

\begin{tabular}{cccccc}
\hline Adsorbent & $\begin{array}{c}\text { Adsorption Capacity } \\
(\mathbf{m g} / \mathbf{g})\end{array}$ & Particle Size & $\mathbf{p H}$ & $\begin{array}{c}\text { Temperature } \\
\left({ }^{\circ} \mathbf{C}\right)\end{array}$ & Reference \\
\hline Papaya seeds & 555.56 & $125-250 \mu \mathrm{m}$ & 4.00 & 30 & {$[74]$} \\
Periwinkle shells & 500 & $150 \mu \mathrm{m}$ & 7.00 & 25 & {$[75]$} \\
Date stones & 398.19 & $250 \mu \mathrm{m}$ & 7.00 & 30 & {$[76]$} \\
Bamboo activated carbon & 286 & $1-2 \mathrm{~mm}$ & 3.70 & 25 & {$[77]$} \\
Chitosan beads & 262 & $4.42 \mathrm{~mm}$ & $\mathrm{NA}$ & 30 & {$[78]$} \\
Pea shells & 246.91 & $212 \mu \mathrm{m}$ & $\mathrm{NA}$ & 25 & {$[79]$} \\
Alfa grass & 200 & $500-650 \mu \mathrm{m}$ & 12.0 & 20 & {$[80]$} \\
Broad bean peels & 192.7 & $350-400 \mu \mathrm{m}$ & 5.00 & 30 & {$[81]$} \\
Garlic peels & 142.86 & $\mathrm{NA}$ & 6.00 & 50 & {$[82]$} \\
Natural poplar leaf & 135.35 & $0.425-0.850 \mathrm{~mm}$ & 7.00 & 20 & {$[83]$} \\
Pine-tree leaf biomass & 126.58 & $<350 \mu \mathrm{m}$ & 9.20 & 30 & {$[84]$} \\
Modified clay-ball & 100 & $1-2 \mathrm{~mm}$ & $\mathrm{NA}$ & 50 & {$[85]$} \\
Palm kernel fiber & 95.4 & $50-80 \mu \mathrm{m}$ & 7.20 & 25 & {$[49]$} \\
Peanut husk & 72.13 & $0.425-0.85 \mathrm{~mm}$ & 7.00 & 20 & {$[27]$} \\
Wheat bran & 54.79 & $150-250 \mu \mathrm{m}$ & 6.00 & 20 & {$[86]$} \\
Rice husk & 25.46 & $0.075-1.16 \mathrm{~mm}$ & 7.00 & 25 & This study \\
Rice bran & 20.29 & $150-250 \mu \mathrm{m}$ & 6.00 & 20 & {$[86]$} \\
\hline
\end{tabular}




\subsection{Thermodynamics}

To better comprehend the thermal impact, the adsorption process was conducted at temperatures of $15{ }^{\circ} \mathrm{C}, 25{ }^{\circ} \mathrm{C}$ and $35{ }^{\circ} \mathrm{C}$. Table 4 shows the magnitude and extent of the adsorption processes. The positive values of $\Delta \mathrm{H}^{\circ}$ were $151.53 \mathrm{~kJ} / \mathrm{mol}$ and $28.50 \mathrm{~kJ} / \mathrm{mol}$ for $\mathrm{MB}$ and $\mathrm{CV}$, respectively, affirming that the adsorption of $\mathrm{MB}$ and $\mathrm{CV}$ onto $\mathrm{RH}$ was endothermic [87]. The type of adsorption may be derived from the magnitude of $\Delta \mathrm{H}^{\circ}$ : physisorption, when $\Delta \mathrm{H}^{\circ}<20 \mathrm{~kJ} \mathrm{~mol}^{-1}$; ionic exchange, if $\Delta \mathrm{H}^{\circ}$ falls between 20 and $40 \mathrm{~kJ} \mathrm{~mol}^{-1}$; and chemisorption, when $\Delta \mathrm{H}^{\circ}>40 \mathrm{~kJ} \mathrm{~mol}^{-1}$ [88,89]. Therefore, the adsorption of $\mathrm{MB}$ and $\mathrm{CV}$ onto $\mathrm{RH}$ demonstrates ionic exchange and chemisorption, respectively. In addition, the positive values of $\Delta \mathrm{S}^{\circ}$ suggested an increase in haphazardness at the solid/solution interface during the adsorption of $\mathrm{MB}$ and $\mathrm{CV}$ onto $\mathrm{RH}[87,90]$. The negative values of Gibb's free energy change $\left(\Delta G^{\circ}\right)$ with increasing temperature revealed the spontaneous adsorption of $M B$ and $\mathrm{CV}$ onto $\mathrm{RH}$. More so, the decrease in $\Delta \mathrm{G}^{\circ}$ with increasing temperature indicated that the adsorption process of both dyes on the $\mathrm{RH}$ was more favorable at higher temperatures, probably due to the rise in dye molecules movement in solution.

Table 4. Thermodynamic parameters for adsorption of methylene blue (MB) and crystal violet (CV) on rice husk. $\Delta H^{\circ}$ : the change in enthalpy $(\mathrm{kJ} / \mathrm{mol}) ; \Delta S^{\circ}$ : the change in entropy $(\mathrm{J} / \mathrm{mol} \mathrm{K}) ; \Delta G^{\circ}$ : the change in Gibb's free energy $(\mathrm{kJ} / \mathrm{mol})$.

\begin{tabular}{|c|c|c|c|c|}
\hline Adsorbate & $\begin{array}{c}\text { Temperature } \\
\text { (K) }\end{array}$ & $\begin{array}{c}\Delta H^{\circ} \\
(\mathrm{kJ} / \mathrm{mol})\end{array}$ & $\begin{array}{c}\Delta S^{\circ} \\
(\mathrm{J} / \mathrm{mol} \mathrm{K})\end{array}$ & $\begin{array}{c}\Delta G^{\circ} \\
(\mathrm{kJ} / \mathrm{mol})\end{array}$ \\
\hline $\mathrm{MB}$ & $\begin{array}{l}288 \\
298 \\
308\end{array}$ & 28.50 & 0.103 & $\begin{array}{l}-1.1115 \\
-1.9774 \\
-3.1703\end{array}$ \\
\hline $\mathrm{CV}$ & $\begin{array}{l}288 \\
298 \\
308\end{array}$ & 151.53 & 0.535 & $\begin{array}{r}-2.7018 \\
-7.6901 \\
-13.4146\end{array}$ \\
\hline
\end{tabular}

\subsection{Influence of solution $\mathrm{pH}$}

The adsorption of $\mathrm{MB}$ and $\mathrm{CV}$ onto $\mathrm{RH}$ (Figure 6), is presented concerning solution $\mathrm{pH}$ as the $\mathrm{pH}$ increased from 4 to 10 . The removal percentages of $\mathrm{MB}$ and $\mathrm{CV}$ all exceeded $95 \%$ at the $\mathrm{pH}$ range of 4-10. The adsorption capacity of molecules of both, $\mathrm{MB}$ and $\mathrm{CV}$, increased as $\mathrm{pH}$ increased from 4 to 10 , even though the increase was insignificant. The adsorption efficiency is dependent on the solution $\mathrm{pH}$, as variation in $\mathrm{pH}$ affects the degree of ionization of adsorptive molecules and the adsorbent surface properties [91]. $\mathrm{MB}$ and $\mathrm{CV}$ are cationic dyes that exist in an aqueous solution as positively charged ions. Consequently, for charged molecules, the degree of adsorption of these cations onto the surface of the RH could be primarily impacted by the surface charge of the adsorbent, which is dependent on the solution $\mathrm{pH}$. The point of zero charge (pHpzc) of unmodified $\mathrm{RH}$ has a value of 2.7 [92]; when the solution $\mathrm{pH}>\mathrm{pHpzc}$, the surface of the adsorbent is negatively charged, with more functional groups available for bonding (attributed to deprotonation). In this experimental condition ( $\mathrm{pH}>4$ ), there was an electrostatic interaction between positively charged dyes and the negatively charged surface of RH particles, prompting favorable adsorption but the electrostatic repulsion between anionic dyes and $\mathrm{RH}$ surfaces. This can alternatively be explained by other adsorption methods, e.g., ion exchange, which is consistent with other studies [93]. 


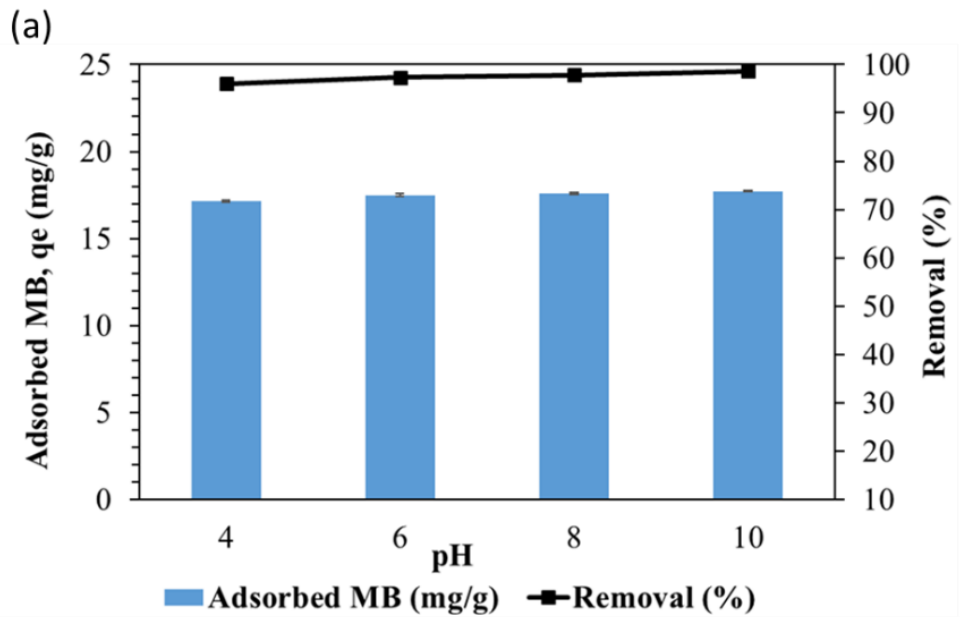

(b)

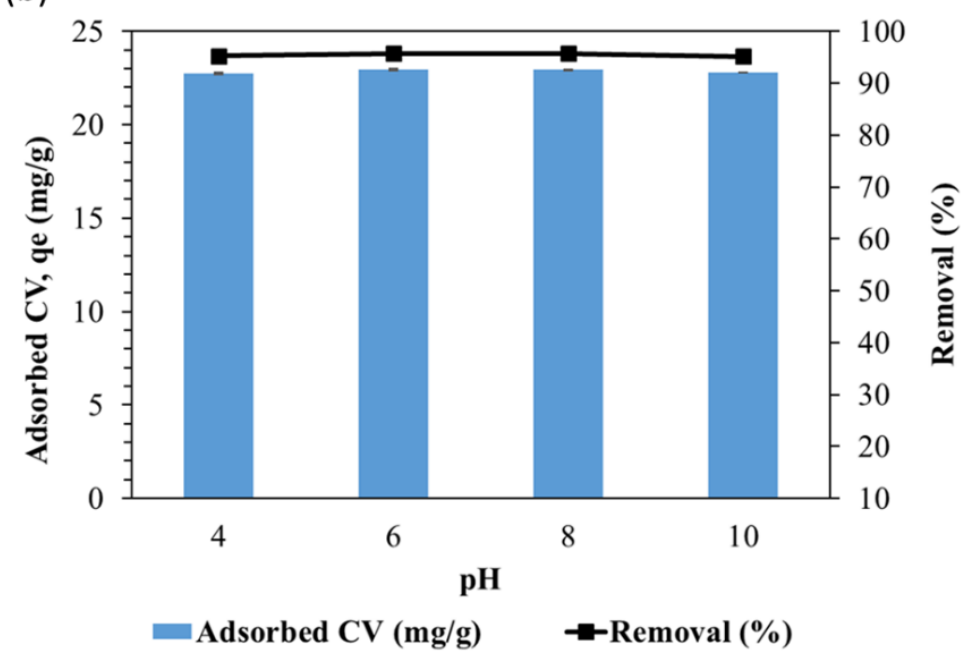

Figure 6. Influence of solution $\mathrm{pH}(4-10)$ on (a) methylene blue (MB) adsorption and (b) crystal violet (CV) adsorption.

\subsection{Effect of Adsorbent Dosage}

The efficiency of any adsorbent in the treatment of polluted wastewaters depends mainly on the number of available active adsorption sites [49]. To enhance the removal efficiency of RH and find the optimum dosage amounts, the adsorption capacity of $\mathrm{RH}$ and removal percentage were analyzed by varying the dosage in the range of $0.05-1.0 \mathrm{~g}$ at initial dye concentrations of $400 \mathrm{mg} / \mathrm{L}(\mathrm{MB})$ and $300 \mathrm{mg} / \mathrm{L}(\mathrm{CV})$. The results, as plotted in Figure 7, indicate that the MB removal percentage marked up from $53.74 \%$ to $97.74 \%$ while that of CV increased from $57.40 \%$ to $98.19 \%$. The increase may be attributed to the increase in the number of adsorption sites [6,19]. In contrast, with an increasing dose of RH, the adsorption capacity of MB and CV onto RH decreased from $160.41 \mathrm{mg} / \mathrm{g}$ to $25.6 \mathrm{mg} / \mathrm{g}$ and $68.81 \mathrm{mg} / \mathrm{g}$ to $11.78 \mathrm{mg} / \mathrm{g}$, respectively. This decrease could be attributed to the split in the flux or concentration gradient between the solute in solution and solute at the surface of the adsorbent, or to the overlaying of adsorption sites following a reduction in the total adsorption surface-area available to the dye, and a rise in the diffusion pathway. Therefore, the amount of MB and CV adsorbed onto unit weight of RH is reduced, leading to a decrease in the adsorption capacity. 

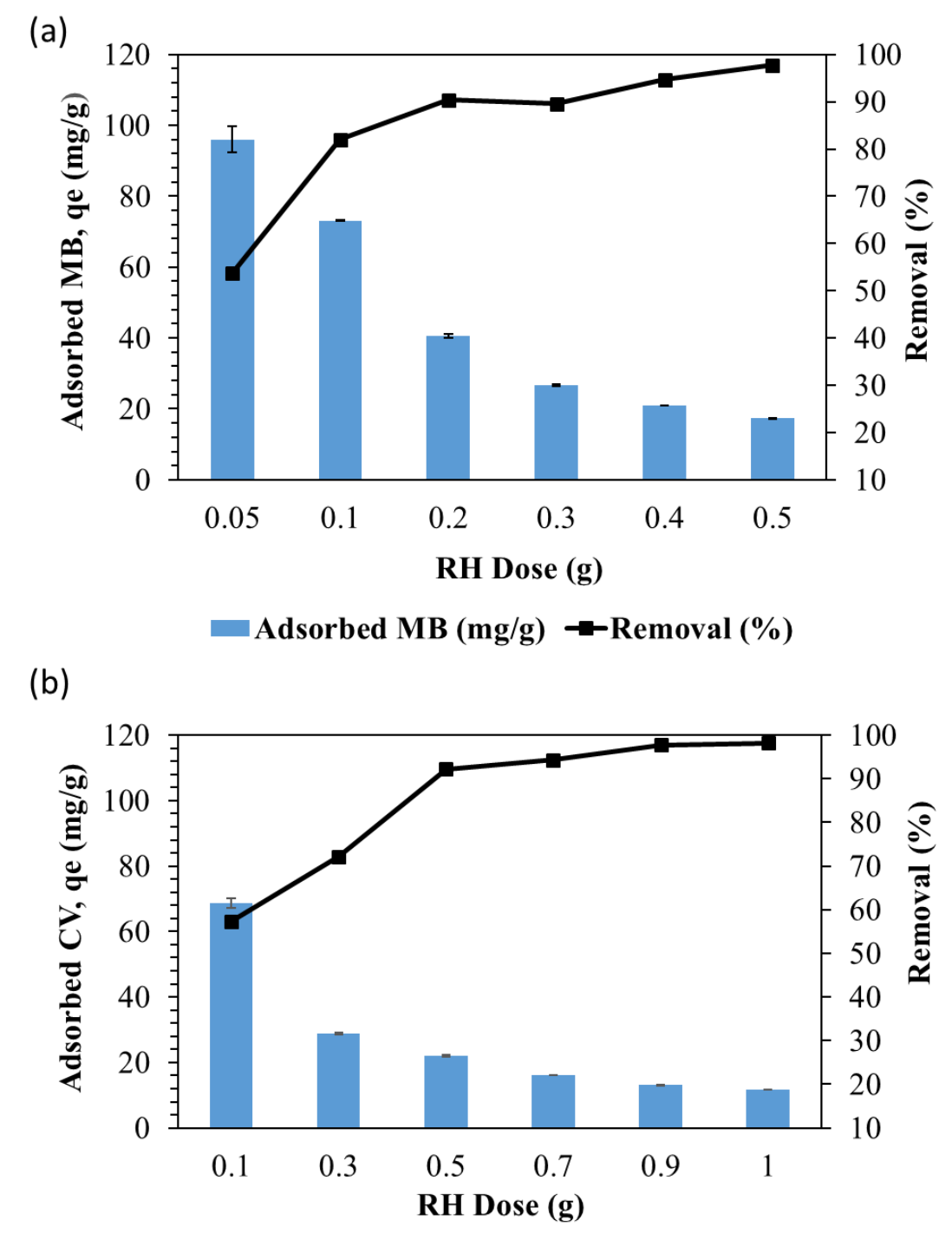

Adsorbed CV (mg/g) $\rightarrow-$ Removal (\%)

Figure 7. Effect of rice husk (RH) dosage on (a) methylene blue (MB) adsorption and (b) crystal violet (CV) adsorption

\section{Conclusions}

$\mathrm{RH}$, an agricultural byproduct, was utilized as an affordable resource to remove $\mathrm{MB}$ and $\mathrm{CV}$ from an aqueous solution. Pyrolysis of the $\mathrm{RH}$ above $300{ }^{\circ} \mathrm{C}$ was ineffective in enhancing its adsorption capacity for $\mathrm{MB}$ and it was opposite to the removal of dyes by the adsorbents derived from biomass. $\mathrm{RH}$ treated at $75^{\circ} \mathrm{C}$, had a superior removal capacity than $\mathrm{RH}$ at other temperatures $\left(100{ }^{\circ} \mathrm{C}, 300^{\circ} \mathrm{C}\right.$, $500{ }^{\circ} \mathrm{C}$, and $700^{\circ} \mathrm{C}$ ). The kinetic adsorption for $\mathrm{MB}$ and $\mathrm{CV}$ was well represented by the $\mathrm{PFO}$ model and PSO model, respectively. The adsorption rate of MB by RH was mainly dominated by film-diffusion or intra-particle diffusion, but the adsorption for $\mathrm{CV}$ was by chemisorption. The equilibrium adsorption of both MB and CV by RH were well-fitted to the Langmuir model, revealing a homogenous monolayer coverage of $\mathrm{MB}$ and $\mathrm{CV}$ on the outer surface of the RH. The adsorption of MB and CV onto RH was endothermic and spontaneous. Solution $\mathrm{pH}$ barely influenced the adsorption of both, MB and CV onto RH. An increasing RH dosage led to an increase in the removal percentage and a decrease in the adsorbed dyes per unit mass of RH. The adsorption capacity of RH for both, MB and CV was lower than that of other adsorbents in the literature; however, it can be a good candidate for the removal of $\mathrm{MB}$ and $\mathrm{CV}$ from textile wastewater due to its low price and availability. 
Author Contributions: J.O.Q.: Visualization, Writing-original draft; T.H.: Experiment, Data curation; F.N.L.: Writing-review and editing; P.P.K.: Experiment, Data curation; S.-H.H.: Conceptualization; C.-G.L.: Investigation, Validation; S.-J.P.: Conceptualization, Writing-review and editing, Supervision, Funding acquisition. All authors have read and agreed to the published version of the manuscript.

Funding: This work was supported by Korea Institute of Planning and Evaluation for Technology in Food, Agriculture, Forestry and Fisheries (IPET) through Advanced Production Technology Development Program, funded by Ministry of Agriculture, Food and Rural Affairs (MAFRA) (Grant No. 317017-03).

Conflicts of Interest: The authors declare no conflict of interest.

\section{References}

1. Bağda, E. The feasibility of using Rosa canina galls as an effective new biosorbent for removal of methylene blue and crystal violet. Desalin. Water Treat. 2012, 43, 63-75. [CrossRef]

2. Alizadeh, N.; Shariati, S.; Besharati, N. Adsorption of crystal violet and methylene blue on azolla and fig leaves modified with magnetite iron oxide nanoparticles. Int. J. Environ. Health Res. 2017, 11, $197-206$. [CrossRef]

3. Levin, R.L.; Degrange, M.A.; Bruno, G.F.; Del Mazo, C.D.; Taborda, D.J.; Griotti, J.J.; Boullon, F.J. Methylene blue reduces mortality and morbidity in vasoplegic patients after cardiac surgery. Ann. Thorac. Surg. 2004, 77, 496-499. [CrossRef]

4. Wu, Y.; Zhang, L.; Gao, C.; Ma, J.; Ma, X.; Han, R. Adsorption of Copper Ions and Methylene Blue in a Single and Binary System on Wheat Straw. J. Chem. Eng. Data 2009, 54, 3229-3234. [CrossRef]

5. Rafatullah, M.; Sulaiman, O.; Hashim, R.; Ahmad, A. Adsorption of methylene blue on low-cost adsorbents: A review. J. Hazard. Mater. 2010, 177, 70-80. [CrossRef]

6. Ahmad, R. Studies on adsorption of crystal violet dye from aqueous solution onto coniferous pinus bark powder (CPBP). J. Hazard. Mater. 2009, 171, 767-773. [CrossRef]

7. Chen, C.C.; Liao, H.J.; Cheng, C.Y.; Yen, C.Y.; Chung, Y.C. Biodegradation of crystal violet by Pseudomonas putida. Biotechnol. Lett. 2007, 29, 391-396. [CrossRef]

8. Kumar, R.; Ahmad, R. Biosorption of hazardous crystal violet dye from aqueous solution onto treated ginger waste (TGW). Desalination 2011, 265, 112-118. [CrossRef]

9. Santhi, T.; Manonmani, S.; Smitha, T. Removal of malachite green from aqueous solution by activated carbon prepared from the epicarp of Ricinus communis by adsorption. J. Hazard. Mater. 2010, 179, 178-186. [CrossRef]

10. Shanmugam, S.; Rajasekaran, P.; Thanikal, J.V. Synthetic dye decolourization, textile dye and paper industrial effluent treatment using white rot fungi Lentines edodes. Desalin. Water Treat. 2009, 4, 143-147. [CrossRef]

11. Ciardelli, G.; Ranieri, N. The treatment and reuse of wastewater in the textile industry by means of ozonation and electroflocculation. Water Res. 2001, 35, 567-572. [CrossRef]

12. Jirankova, H.; Mrazek, J.; Dolecek, P.; Cakl, J. Organic dye removal by combined adsorption-membrane separation process. Desalin. Water Treat. 2010, 20, 96-101. [CrossRef]

13. Ghosh, M.; Liu, J.; Chuang, S.S.; Jana, S.C. Fabrication of hierarchical $\mathrm{V}_{2} \mathrm{O}_{5}$ nanorods on $\mathrm{TiO}_{2}$ nanofibers and their enhanced photocatalytic activity under visible light. Chem. Cat. Chem. 2018, 10, 3305-3318.

14. Miklos, D.B.; Remy, C.; Jekel, M.; Linden, K.G.; Drewes, J.E.; Hübner, U. Evaluation of advanced oxidation processes for water and wastewater treatment-A critical review. Water Res. 2018, 139, 118-131. [CrossRef] [PubMed]

15. Kyriakopoulos, J.; Kordouli, E.; Bourikas, K.; Kordulis, C.; Lycourghiotis, A. Decolorization of Orange-G aqueous solutions over $\mathrm{C}_{60} / \mathrm{MCM}-41$ photocatalysts. Appl. Sci. 2019, 9, 1958. [CrossRef]

16. Wang, A.; Qu, J.; Liu, H.; Ge, J. Degradation of azo dye Acid Red 14 in aqueous solution by electrokinetic and electrooxidation process. Chemosphere 2004, 55, 1189-1196. [CrossRef]

17. Yang, Z.; Yang, H.; Jiang, Z.; Cai, T.; Li, H.; Li, H.; Li, A.; Cheng, R. Flocculation of both anionic and cationic dyes in aqueous solutions by the amphoteric grafting flocculant carboxymethyl chitosan-graft-polyacrylamide. J. Hazard. Mater. 2013, 254, 36-45. [CrossRef]

18. Liang, C.Z.; Sun, S.P.; Li, F.Y.; Ong, Y.K.; Chung, T.S. Treatment of highly concentrated wastewater containing multiple synthetic dyes by a combined process of coagulation/flocculation and nanofiltration. J. Membr. Sci. 2014, 469, 306-315. [CrossRef] 
19. Cheruiyot, G.K.; Wanyonyi, W.C.; Kiplimo, J.J.; Maina, E.N. Adsorption of toxic crystal violet dye using coffee husks: Equilibrium, kinetics and thermodynamics study. Sci. Afr. 2019, 5, e00116. [CrossRef]

20. Al-Bastaki, N. Removal of methyl orange dye and $\mathrm{Na}_{2} \mathrm{SO}_{4}$ salt from synthetic waste water using reverse osmosis. Chem. Eng. Process 2004, 43, 1561-1567. [CrossRef]

21. Oei, B.C.; Ibrahim, S.; Wang, S.; Ang, H.M. Surfactant modified barley straw for removal of acid and reactive dyes from aqueous solution. Bioresour. Technol. 2009, 100, 4292-4295. [CrossRef] [PubMed]

22. Taştan, B.E.; Ertuğrul, S.; Dönmez, G. Effective bioremoval of reactive dye and heavy metals by Aspergillus versicolor. Bioresour. Technol. 2010, 101, 870-876. [CrossRef] [PubMed]

23. Gomez, V.; Larrechi, M.; Callao, M. Kinetic and adsorption study of acid dye removal using activated carbon. Chemosphere 2007, 69, 1151-1158. [CrossRef] [PubMed]

24. Malik, P. Dye removal from wastewater using activated carbon developed from sawdust: Adsorption equilibrium and kinetics. J. Hazard. Mater. 2004, 113, 81-88. [CrossRef]

25. Gupta, V.K.; Sharma, S. Removal of zinc from aqueous solutions using bagasse fly ash- a low cost adsorbent. Ind. Eng. Chem. Res. 2003, 42, 6619-6624. [CrossRef]

26. Gupta, V. Application of low-cost adsorbents for dye removal-A review. J. Environ. Manag. 2009, 90, 2313-2342. [CrossRef]

27. Song, J.; Zou, W.; Bian, Y.; Su, F.; Han, R. Adsorption characteristics of methylene blue by peanut husk in batch and column modes. Desalination 2011, 265, 119-125. [CrossRef]

28. Wang, Z.; Han, P.; Jiao, Y.; Ma, D.; Dou, C.; Han, R. Adsorption of congo red using ethylenediamine modified wheat straw. Desalin. Water Treat. 2011, 30, 195-206. [CrossRef]

29. Franca, A.S.; Oliveira, L.S.; Saldanha, S.A.; Santos, P.I.; Salum, S.S. Malachite green adsorption by mango (Mangifera indica L.) seed husks: Kinetic, equilibrium and thermodynamic studies. Desalin. Water Treat. 2010, 19, 241-248. [CrossRef]

30. Aydin, H.; Baysal, G.; Bulut, Y. Utilization of walnut shells (Juglans regia) as an adsorbent for the removal of acid dyes. Desalin. Water Treat. 2009, 2, 141-150. [CrossRef]

31. Khattri, S.; Singh, M. Removal of malachite green from dye wastewater using neem sawdust by adsorption. J. Hazard. Mater. 2009, 167, 1089-1094. [CrossRef] [PubMed]

32. Garg, V.K.; Amita, M.; Kumar, R.; Gupta, R. Basic dye (methylene blue) removal from simulated wastewater by adsorption using Indian Rosewood sawdust: A timber industry waste. Dyes Pigm. 2004, 63, 243-250. [CrossRef]

33. Mane, R.; Bhusari, V. Removal of colour (dyes) from textile effluent by adsorption using orange and banana peel. Int. J. Eng. Res. Appl. 2012, 2, 1997-2004.

34. Foo, K.; Hameed, B. Preparation of activated carbon from date stones by microwave induced chemical activation: Application for methylene blue adsorption. Chem. Eng. J. 2011, 170, 338-341. [CrossRef]

35. Kumar, P.S.; Ramalingam, S.; Senthamarai, C.; Niranjanaa, M.; Vijayalakshmi, P.; Sivanesan, S. Adsorption of dye from aqueous solution by cashew nut shell: Studies on equilibrium isotherm, kinetics and thermodynamics of interactions. Desalination 2010, 261, 52-60. [CrossRef]

36. Juang, R.S.; Wu, F.C.; Tseng, R.L. Mechanism of adsorption of dyes and phenols from water using activated carbons prepared from plum kernels. J. Colloid Interface Sci. 2000, 227, 437-444. [CrossRef] [PubMed]

37. Tripathi, A.; Ranjan, M.R. Heavy metal removal from wastewater using low cost adsorbents. J. Bioremediat. Biodegrad. 2015, 6, 1-5. [CrossRef]

38. Adegoke, K.A.; Bello, O.S. Dye sequestration using agricultural wastes as adsorbents. Water Resour. Ind. 2015, 12, 8-24. [CrossRef]

39. Savova, D.; Apak, E.; Ekinci, E.; Yardim, F.; Petrov, N.; Budinova, T.; Razvigorova, M.; Minkova, V. Biomass conversion to carbon adsorbents and gas. Biomass Bioenergy 2001, 21, 133-142. [CrossRef]

40. Li, Y.; Ding, X.; Guo, Y.; Rong, C.; Wang, L.; Qu, Y.; Ma, X.; Wang, Z. A new method of comprehensive utilization of rice husk. J. Hazard. Mater. 2011, 186, 2151-2156. [CrossRef]

41. Tong, K.T.; Vinai, R.; Soutsos, M.N. Use of Vietnamese rice husk ash for the production of sodium silicate as the activator for alkali-activated binders. J. Clean. Prod. 2018, 201, 272-286. [CrossRef]

42. Food and Agriculture Organization of the United Nations. Food balance sheets; FAO Communication: Rome, Italy, 2018. 
43. Chowdhury, S.; Saha, P.D. Artificial neural network (ANN) modeling of adsorption of methylene blue by $\mathrm{NaOH}$-modified rice husk in a fixed-bed column system. Environ. Sci. Pollut. Res. 2013, 20, 1050-1058. [CrossRef] [PubMed]

44. Chakraborty, S.; Chowdhury, S.; Saha, P.D. Adsorption of crystal violet from aqueous solution onto $\mathrm{NaOH}$-modified rice husk. Carbohydr. Polym. 2011, 86, 1533-1541. [CrossRef]

45. Chuah, T.G.; Jumasiah, A.; Azni, I.; Katayon, S.; Choong, S.T. Rice husk as a potentially low-cost biosorbent for heavy metal and dye removal: An overview. Desalination 2005, 175, 305-316. [CrossRef]

46. Ahmad, W.; Yang, Z.; Khan, J.; Jing, W.; Jiang, F.; Chu, L.; Liu, N.; Li, L.; Gao, Y. Extraction of nano-silicon with activated carbons simultaneously from rice husk and their synergistic catalytic effect in counter electrodes of dye-sensitized solar cells. Sci. Rep. 2016, 6, 1-11. [CrossRef]

47. Yadav, S.; Asthana, A.; Chakraborty, R.; Jain, B.; Singh, A.K.; Carabineiro, S.A.; Susan, M.; Hassan, A.B. Cationic Dye Removal Using Novel Magnetic/Activated Charcoal/ $\beta$-Cyclodextrin/Alginate Polymer Nanocomposite. J. Nanomater. 2020, 10, 170. [CrossRef]

48. Doble, M.; Kumar, A. Biotreatment of Industrial Effluents; Elsevier: Waltham, MA, USA, 24 February 2005.

49. El-Sayed, G.O. Removal of methylene blue and crystal violet from aqueous solutions by palm kernel fiber. Desalination 2011, 272, 225-232. [CrossRef]

50. Hong, S.H.; Lyonga, F.N.; Kang, J.K.; Seo, E.J.; Lee, C.G.; Jeong, S.; Hong, S.G.; Park, S.J. Synthesis of Fe-impregnated biochar from food waste for Selenium (VI)removal from aqueous solution through adsorption: Process optimization and assessment. Chemosphere 2020, 252, 126475. [CrossRef]

51. Lee, J.I.; Hong, S.H.; Lee, C.G.; Park, S.J. Experimental and model study for fluoride removal by thermally activated sepiolite. Chemosphere 2020, 241, 125094. [CrossRef]

52. Wang, X.S.; Lin, H.Q. Adsorption of basic dyes by dried waste sludge: Kinetic, equilibrium and desorption studies. Desalin. Water Treat. 2011, 29, 10-19. [CrossRef]

53. Della, V.P.; Kühn, I.; Hotza, D. Rice husk ash as an alternate source for active silica production. Mater. Lett. 2002, 57, 818-821. [CrossRef]

54. Chandrasekhar, S.; Pramada, P. Rice husk ash as an adsorbent for methylene blue-Effect of ashing temperature. Adsorption 2006, 12, 27. [CrossRef]

55. Chen, Y.; Zhu, Y.; Wang, Z.; Li, Y.; Wang, L.; Ding, L.; Gao, X.; Ma, Y.; Guo, Y. Application studies of activated carbon derived from rice husks produced by chemical-thermal process-A review. Adv. Colloid Interface Sci. 2011, 163, 39-52. [CrossRef] [PubMed]

56. Deiana, C.; Granados, D.; Venturini, R.; Amaya, A.; Sergio, M.; Tancredi, N. Activated carbons obtained from rice husk: Influence of leaching on textural parameters. Ind. Eng. Chem. Res. 2008, 47, 4754-4757. [CrossRef]

57. Sakin Omer, O.; Hussein, M.A.; Hussein, B.H.M.; Mgaidi, A. Adsorption thermodynamics of cationic dyes (methylene blue and crystal violet) to a natural clay mineral from aqueous solution between 293.15 and 323.15 K. Arab. J. Chem. 2018, 11, 615-623. [CrossRef]

58. Cazetta, A.L.; Vargas, A.M.M.; Nogami, E.M.; Kunita, M.H.; Guilherme, M.R.; Martins, A.C.; Silva, T.L.; Moraes, J.C.G.; Almeida, V.C. NaOH-activated carbon of high surface area produced from coconut shell: Kinetics and equilibrium studies from the methylene blue adsorption. Chem. Eng. J. 2011, 174, 117-125. [CrossRef]

59. Ho, Y.S.; Mckay, G. The kinetics of sorption of basic dyes from aqueous solution by sphagnum moss peat. Can. J. Chem. Eng. 1998, 76, 822-827. [CrossRef]

60. Tharaneedhar, V.; Kumar, P.S.; Saravanan, A.; Ravikumar, C.; Jaikumar, V. Prediction and interpretation of adsorption parameters for the sequestration of methylene blue dye from aqueous solution using microwave assisted corncob activated carbon. Sustain. Mater. Technol. 2017, 11,1-11. [CrossRef]

61. Ho, Y.S.; McKay, G. Pseudo-second order model for sorption processes. Process Biochem. 1999, 34, 451-465. [CrossRef]

62. Cheung, W.; Szeto, Y.; McKay, G. Intraparticle diffusion processes during acid dye adsorption onto chitosan. Bioresour. Technol. 2007, 98, 2897-2904. [CrossRef]

63. Ramírez-Rodríguez, T.; De Landa Castillo-Alvarado, F. Application of the intra-particle diffusion model for activated carbon fibers in an aqueous medium. Mater. Res. Soc. Symp. Proc. 2012, 1373. [CrossRef]

64. Wu, F.C.; Tseng, R.L.; Juang, R.S. Initial behavior of intraparticle diffusion model used in the description of adsorption kinetics. Chem. Eng. J. 2009, 153, 1-8. [CrossRef] 
65. Wang, X.S.; Liu, X.; Wen, L.; Zhou, Y.; Jiang, Y.; Li, Z. Comparison of Basic Dye Crystal Violet Removal from Aqueous Solution by Low-Cost Biosorbents. Sep. Sci. Technol. 2008, 43, 3712-3731. [CrossRef]

66. Hu, L.; Guang, C.; Liu, Y.; Su, Z.; Gong, S.; Yao, Y.; Wang, Y. Adsorption behavior of dyes from an aqueous solution onto composite magnetic lignin adsorbent. Chemosphere 2020, 246, 125757. [CrossRef]

67. Jayasantha Kumari, H.; Krishnamoorthy, P.; Arumugam, T.K.; Radhakrishnan, S.; Vasudevan, D. An efficient removal of crystal violet dye from waste water by adsorption onto TLAC/Chitosan composite: A novel low cost adsorbent. Int. J. Biol. Macromol. 2017, 96, 324-333. [CrossRef]

68. Duraisamy, R.; Kiruthiga, P.; Hirpaye, B.; Berekute, A. Adsorption of azure B dye on rice husk activated carbon: Equilibrium, kinetic and thermodynamic studies. Int. J. Water Res. 2015, 5, 18-28.

69. Mushtaq, M.; Bhatti, H.N.; Iqbal, M.; Noreen, S. Eriobotrya japonica seed biocomposite efficiency for copper adsorption: Isotherms, kinetics, thermodynamic and desorption studies. J. Environ. Manag. 2016, 176, 21-33. [CrossRef]

70. Atmani, F.; Bensmaili, A.; Mezenner, N. Synthetic textile effluent removal by skin almonds waste. J. Environ. Sci. Technol. 2009, 2, 153-169. [CrossRef]

71. Foo, K.Y.; Hameed, B.H. Insights into the modeling of adsorption isotherm systems. Chem. Eng. J. 2010, 156, 2-10. [CrossRef]

72. Sharma, P.; Kaur, H.; Sharma, M.; Sahore, V. A review on applicability of naturally available adsorbents for the removal of hazardous dyes from aqueous waste. Environ. Monit. Assess. 2011, 183, 151-195. [CrossRef]

73. Chowdhury, S.; Mishra, R.; Saha, P.; Kushwaha, P. Adsorption thermodynamics, kinetics and isosteric heat of adsorption of malachite green onto chemically modified rice husk. Desalination 2011, 265, 159-168. [CrossRef]

74. Hameed, B.H. Evaluation of papaya seeds as a novel non-conventional low-cost adsorbent for removal of methylene blue. J. Hazard. Mater. 2009, 162, 939-944. [CrossRef] [PubMed]

75. Bello, O.S.; Adeogun, I.A.; Ajaelu, J.C.; Fehintola, E.O. Adsorption of methylene blue onto activated carbon derived from periwinkle shells: Kinetics and equilibrium studies. J. Chem. Ecol. 2008, 24, 285-295. [CrossRef]

76. Ahmed, M.J.; Dhedan, S.K. Equilibrium isotherms and kinetics modeling of methylene blue adsorption on agricultural wastes-based activated carbons. Fluid Phase Equilib. 2012, 317, 9-14. [CrossRef]

77. Liu, Q.-S.; Zheng, T.; Li, N.; Wang, P.; Abulikemu, G. Modification of bamboo-based activated carbon using microwave radiation and its effects on the adsorption of methylene blue. Appl. Surf. Sci. 2010, 256, 3309-3315. [CrossRef]

78. Chang, M.-Y.; Juang, R.-S. Adsorption of tannic acid, humic acid, and dyes from water using the composite of chitosan and activated clay. J. Colloid Interface Sci. 2004, 278, 18-25. [CrossRef]

79. Geçgel, Ü.; Özcan, G.; Gürpınar, G.Ç. Removal of methylene blue from aqueous solution by activated carbon prepared from pea shells (Pisum sativum). J. Chem. 2012, 2013, 614083. [CrossRef]

80. Boumehdi Toumi, L.; Hamdi, L.; Salem, Z.; Allia, K. Batch adsorption of methylene blue from aqueous solutions by untreated Alfa grass. Desalin. Water Treat. 2015, 53, 806-817. [CrossRef]

81. Hameed, B.H.; El-Khaiary, M.I. Sorption kinetics and isotherm studies of a cationic dye using agricultural waste: Broad bean peels. J. Hazard. Mater. 2008, 154, 639-648. [CrossRef]

82. Hameed, B.; Ahmad, A. Batch adsorption of methylene blue from aqueous solution by garlic peel, an agricultural waste biomass. J. Hazard. Mater. 2009, 164, 870-875. [CrossRef]

83. Han, X.; Niu, X.; Ma, X. Adsorption characteristics of methylene blue on poplar leaf in batch mode: Equilibrium, kinetics and thermodynamics. Korean J. Chem. Eng. 2012, 29, 494-502. [CrossRef]

84. Yagub, M.T.; Sen, T.K.; Ang, H. Equilibrium, kinetics, and thermodynamics of methylene blue adsorption by pine tree leaves. Water Air Soil Pollut. 2012, 223, 5267-5282. [CrossRef]

85. Auta, M.; Hameed, B.H. Modified mesoporous clay adsorbent for adsorption isotherm and kinetics of methylene blue. Chem. Eng. J. 2012, 198, 219-227. [CrossRef]

86. Wang, X.S.; Zhou, Y.; Jiang, Y.; Sun, C. The removal of basic dyes from aqueous solutions using agricultural by-products. J. Hazard. Mater. 2008, 157, 374-385. [CrossRef]

87. Ertaş, M.; Acemioğlu, B.; Alma, M.H.; Usta, M. Removal of methylene blue from aqueous solution using cotton stalk, cotton waste and cotton dust. J. Hazard. Mater. 2010, 183, 421-427. [CrossRef]

88. Monárrez-Cordero, B.E.; Sáenz-Trevizo, A.; Bautista-Carrillo, L.M.; Silva-Vidaurri, L.G.; Miki-Yoshida, M.; Amézaga-Madrid, P. Simultaneous and fast removal of As3+, As5+, $\mathrm{Cd} 2+, \mathrm{Cu} 2+, \mathrm{Pb} 2+$ and F- from water with composite Fe-Ti oxides nanoparticles. J. Alloys Compd. 2018, 757, 150-160. [CrossRef] 
89. Navarathna, C.M.; Karunanayake, A.G.; Gunatilake, S.R.; Pittman, C.U.; Perez, F.; Mohan, D.; Mlsna, T. Removal of Arsenic(III) from water using magnetite precipitated onto Douglas fir biochar. J. Environ. Manag. 2019, 250, 109429. [CrossRef]

90. Hong, S.; Wen, C.; He, J.; Gan, F.; Ho, Y.-S. Adsorption thermodynamics of methylene blue onto bentonite. J. Hazard. Mater. 2009, 167, 630-633. [CrossRef]

91. Nandi, B.; Goswami, A.; Purkait, M. Removal of cationic dyes from aqueous solutions by kaolin: Kinetic and equilibrium studies. Appl. Clay Sci. 2009, 42, 583-590. [CrossRef]

92. Deng, S.; Niu, L.; Bei, Y.; Wang, B.; Huang, J.; Yu, G. Adsorption of perfluorinated compounds on aminated rice husk prepared by atom transfer radical polymerization. Chemosphere 2013, 91, 124-130. [CrossRef]

93. Shittu, I.; Edathil, A.A.; Alsaeedi, A.; Al-Asheh, S.; Polychronopoulou, K.; Banat, F. Development of novel surfactant functionalized porous graphitic carbon as an efficient adsorbent for the removal of methylene blue dye from aqueous solutions. J. Water Process. Eng. 2019, 28, 69-81. [CrossRef]

(C) 2020 by the authors. Licensee MDPI, Basel, Switzerland. This article is an open access article distributed under the terms and conditions of the Creative Commons Attribution (CC BY) license (http://creativecommons.org/licenses/by/4.0/). 